\title{
Functional expression of a penicillin acylase from the extreme thermophile Thermus thermophilus HB27 in Escherichia coli
}

Leticia L Torres, Eloy R Ferreras, Ángel Cantero, Aurelio Hidalgo* and José Berenguer*

\begin{abstract}
Background: Penicillin acylases (PACs) are enzymes of industrial relevance in the manufacture of $\beta$-lactam antibiotics. Development of a PAC with a longer half-life under the reaction conditions used is essential for the improvement of the operational stability of the process. A gene encoding a homologue to Escherichia coli PAC was found in the genome of the thermophilic bacterium Thermus thermophilus (Tth) HB27. Because of the nature of this PAC and its complex maturation that is crucial to reach its functional heterodimeric final conformation, the overexpression of this enzyme in a heterologous mesophilic host was a challenge. Here we describe the purification and characterization of the PAC protein from Tth HB27 overexpressed in Escherichia coli.

Results: Fusions to a superfolder green fluorescent protein and differential membrane solubilization assays indicated that the native enzyme remains attached through its amino-terminal end to the outer side of the cytoplasmic membrane of Tth cells. In order to overexpress this PAC in E. coli cells, a variant of the protein devoid of its membrane anchoring segment was constructed. The effect of the co-expression of chaperones and calcium supplementation of the culture medium was investigated. The total production of PAC was enhanced by the presence of DnaK/J and GrpE and even more by trigger factor and GroEL/ES. In addition, $10 \mathrm{mM}$ calcium markedly improved both PAC specific and volumetric activities. Recombinant PAC was affinity-purified and proper maturation of the protein was confirmed by SDS-PAGE and MALDI-TOF analysis of the subunits. The recombinant protein was tested for activity towards several penicillins, cephalosporins and homoserine lactones. Hydrophobic acyl-chain penicillins were preferred over the rest of the substrates. Penicillin K (octanoyl penicillin) was the best substrate, with the highest specificity constant value $\left(16.12 \mathrm{mM}^{-1}\right.$. $\left.\mathrm{seg}^{-1}\right)$. The optimum $\mathrm{pH}$ was aprox. 4 and the optimum temperature was $75^{\circ} \mathrm{C}$. The half-life of the enzyme at this temperature was $9.2 \mathrm{~h}$.

Conclusions: This is the first report concerning the heterologous expression of a pac gene from a thermophilic microorganism in the mesophilic host E. coli. The recombinant protein was identified as a penicillin K-deacylating thermozyme.
\end{abstract}

Keywords: Penicillin acylase, Thermus thermophilus, Pre-pro-protein, Autoprocessing, Thermophile, Thermozyme

\section{Background}

Penicillin acylase (PAC, EC 3.5.1.11) is one of the most relevant enzymes in the pharmaceutical industry. It is used in the production of 6-amino penicillanic acid (6-APA), which is subsequently used in the chemical synthesis of new lactams with greater effectiveness. PACs

\footnotetext{
*Correspondence: ahidalgo@cbm.uam.es; jberenguer@cbm.uam.es Centro de Biología Molecular "Severo Ochoa" (UAM-CSIC), Nicolás Cabrera 1, 28049 Madrid, Spain
}

\section{Biomed Central

belong to the N-terminal nucleophile hydrolase family, whose members undergo a complex maturation process. In this process, the pre-pro-protein is synthesized and translocated to the periplasm with the concomitant removal of the signal peptide. The resulting pro-protein is then autoproteolyzed in the periplasm rendering the $\beta$-subunit. A second autoproteolysis detaches the $\alpha$-subunit and uncovers the active site by elimination of a spacer peptide [1]. The precision of the maturation process is extremely relevant for the functionality of the final heterodimeric protein ( $\alpha$ - plus $\beta$-subunits). 
Industrially, the penicillin $G$ acylase (PGA) from Escherichia coli is the enzyme of choice, whether recombinant or native. Although the optimum temperature for the hydrolysis of penicillin $\mathrm{G}$ is $50^{\circ} \mathrm{C}$, the enzyme loses stability above $30^{\circ} \mathrm{C}$ and must be used in immobilized form. Other described PGAs with higher stability are those from Alcaligenes faecalis (AfaePGA, $t_{1 / 2}$ of $15 \mathrm{~min}$ at $\left.55^{\circ} \mathrm{C}\right)$, Bacillus badius $\left(t_{1 / 2}\right.$ of $20 \mathrm{~min}$ at $55^{\circ} \mathrm{C}$ ) and Achromobacter xylosoxidans $\left(t_{1 / 2}\right.$ of $55 \mathrm{~min}$ at $\left.55^{\circ} \mathrm{C}\right)$. Their thermostability arises from different reasons such as additional disulfide bonds, more salt bridges or additional buried ionic pairs, respectively [2,3]. However, operational stability of the catalytic process could be strongly improved by the use of enzymes with a longer half-life under the reaction conditions regularly used.

Bearing in mind the above-mentioned limitations of penicillin acylases and the naturally superior operational stability of thermozymes, a putative pac gene (NCBI_accession number TTC1972) was identified in the genome of the thermophilic bacterium Thermus thermophilus (Tth) HB27, a microorganism with an optimum growth temperature of $75^{\circ} \mathrm{C}$ [4]. Enzymes isolated from extreme thermophiles (thermozymes) show an optimum temperature similar to that of maximum growth rate of its source. In addition, thermozymes exhibit an above-average resistance to chemical denaturation, for instance, caused by organic solvents, detergents or $\mathrm{pH}$. Thus, the TthPAC protein would be an extremely stable catalyst suitable for the industrial production of semi-synthetic penicillins. Generally speaking, fermentation of the natural thermophilic host is not economically viable due to the nutritional and energy requirements of the process. Thus, expression of the protein of interest in a recombinant system is usually preferred. However, recombinant expression of proteins from thermophiles in mesophiles is frequently a challenge. In fact, it is estimated that less than $20 \%$ of the ORFs of any extreme thermophile or hyperthermophile genome may be expressed and folded correctly in E. coli [5]. Strategies to improve folding of thermozymes expressed recombinantly in $E$. coli include growth of the host at higher temperature [6], refolding of the denatured protein in the presence of cofactors, or co-expression with chaperones from $E$. coli [7].

In this work, we report the first characterization of a penicillin acylase from a thermophile. With the objective of a potential industrial application in mind:

- we performed differential fractionation of the TthPAC combined with detergent solubility and trypsin accessibility assays and characterized the enzyme as a periplasmic, membrane-bound heterodimer in its native host, which makes TthPAC overproduction in Thermus impractical.
- TthPAC was expressed recombinantly in the cytoplasm of $E$. coli devoid of its signal peptide but nevertheless, the existence of autoproteolytic maturation leading to a functional enzyme was achieved.

- we improved productivity and activity of TthPAC in E. coli by coexpression with chaperones and $\mathrm{Ca}^{2+}$ supplementation, respectively.

- finally, we characterized the enzyme with different amides and determined the enzyme to be most proficient in the hydrolysis of penicillin K, similarly to the acylases of Streptomyces lividans and Actinoplanes utahensis.

\section{Results and discussion}

\section{TthPAC is produced and processed in $T$. thermophilus}

In the first place and in order to be able to study TthPAC production and maturation, we generated antibodies against the $\alpha$ - and $\beta$-subunits of the PAC codified in the Tth HB27 genome, separately produced in E. coli cells. Each antiserum recognized only the corresponding subunit of the PACs from the HB27 and NAR1 Tth strains (Figure 1), demonstrating: (i) their specificity, (ii) the presence of constitutively expressed PAC protein in these strains, and (iii) the existence of a maturation process of the pro-PAC into two subunits, similar to the one described for mesophilic PACs [8,9]. The apparent electrophoretic mobilities of these protein subunits are 22 and $60 \mathrm{kDa}$ for the $\alpha$ - and $\beta$-subunits, respectively.

\section{Subcellular localization of TthPAC}

PACs are soluble enzymes in mesophilic organisms. They are usually periplasmic proteins in Gram-negative bacteria, secreted to the media in most Gram-positive bacteria, and can even be intracellular proteins in particular genera like Bacillus $[10,11]$. However, there is no

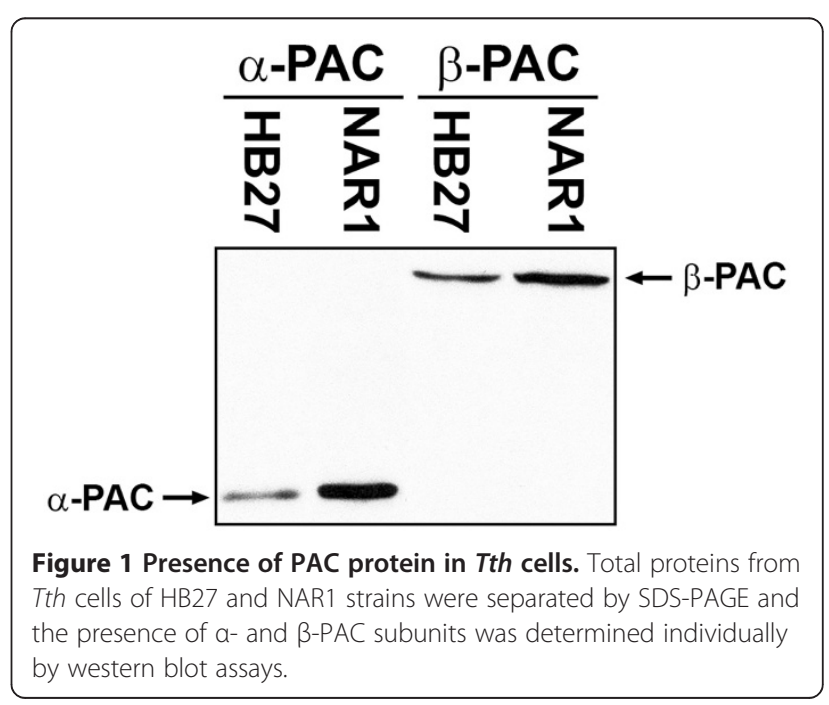


report about the final destination of PAC proteins in thermophilic bacteria. Consequently, in order to shed some light on TthPAC subcellular location, fusions of TthPAC to superfolder GFP (sGFP, a variant of the Aquorea victoria green fluorescent protein that fluoresces properly at $\left.70^{\circ} \mathrm{C}\right)[4,12]$ and membrane differential solubilization assays were performed. The sGFP was fused to the entire TthPAC (TthPAC-sGFP), to a TthPAC devoid of its putative 47-amino acid signal peptide $(\Delta \mathrm{Sp} T$ thPAC-sGFP), to the putative TthPAC signal peptide alone $\left(\mathrm{Sp}_{\text {TthPAC}}-\mathrm{sGFP}\right)$ and to a $\beta$-glycosidase (NCBI accession number YP_006025) used as a cytoplasmic marker ( $\beta$-glycosidase-sGFP). As expected for a cytoplasmic soluble protein, the $\beta$-glycosidase-sGFP fusion resulted in a homogeneous distribution of the fluorescence throughout the bacteria (Figure 2a). In $\triangle \mathrm{Sp} T$ thPAC-sGFP fusions, fluorescence is also located in the cytoplasm but with a defined distribution on central regions of the cells (Figure 2b). When analyzing TthPAC-sGFP or $\mathrm{Sp}_{\text {TthPAC}}$-sGFP fusions, the observed fluorescence intensity was lower and located at polar/ subpolar loci in the envelope of the bacteria, indicating either a membrane or a periplasmic location of the chimeric protein (Figure 2c and 2d).
In order to determine whether TthPAC is being transported to the periplasmic space, we took advantage of the use of a Tth NAR1 mutant in the $\operatorname{slp} A$ (S-layer protein) gene. This strain forms round multicellular bodies surrounded by a common envelope that facilitates purification of periplasmic proteins [13]. DrpA (a nitrate respiration system regulatory protein) was used as a periplasmic protein marker. Surprisingly, we observed that in contrast to what happens in other Gram-negative bacteria, PAC is not being secreted or soluble at all but remains anchored to the membrane of Tth NAR1 $\Delta s l p A$ cells (Figure 3). Note that DrpA is present in the soluble fraction because of the extraction method employed, which cannot deal with undisrupted multicellular bodies or single cells.

The use of the mild detergent Sarkosyl has been described as a method to selectively solubilize inner membrane proteins of Gram-negative bacteria [14-17]. PAC and the inner membrane marker Nqo1 became soluble after the detergent treatment, while SlpA, an outer membrane protein, remained insoluble under the same conditions (Figure 4). These data indicate that PAC is anchored to the inner membrane of Tth cells.

Whether PAC is oriented towards the cytoplasm or the periplasmic space of Tth cells was studied through

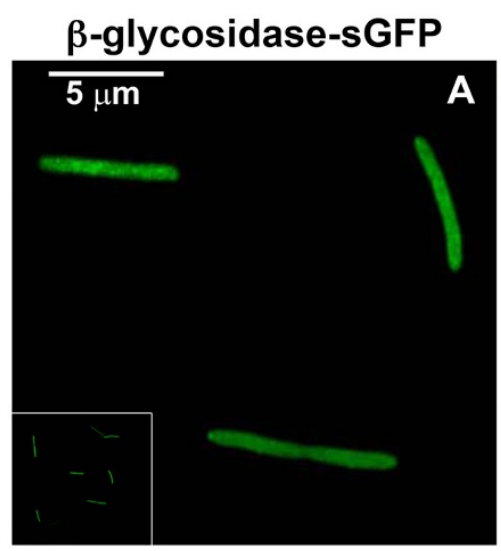

TthPAC-sGFP

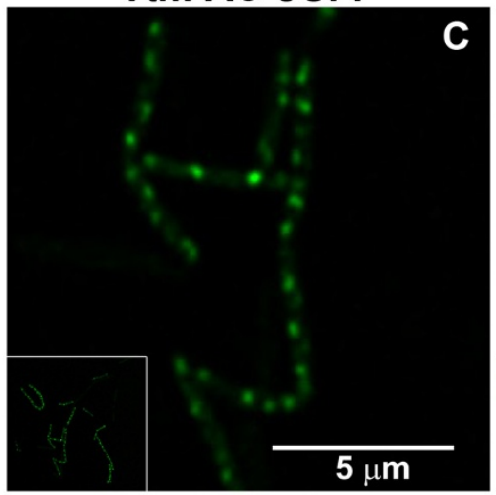

\section{$\triangle$ SpTthPAC-SGFP}

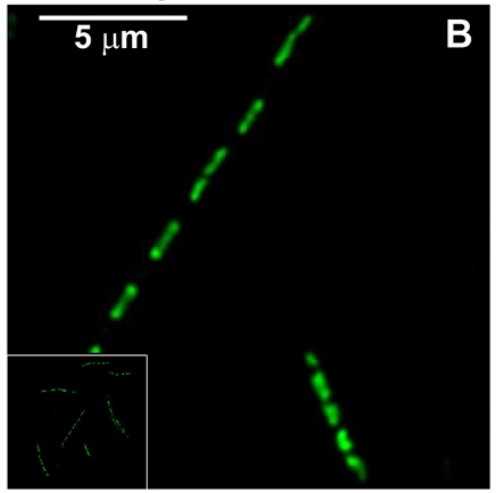

SpTthPAC-SGFP

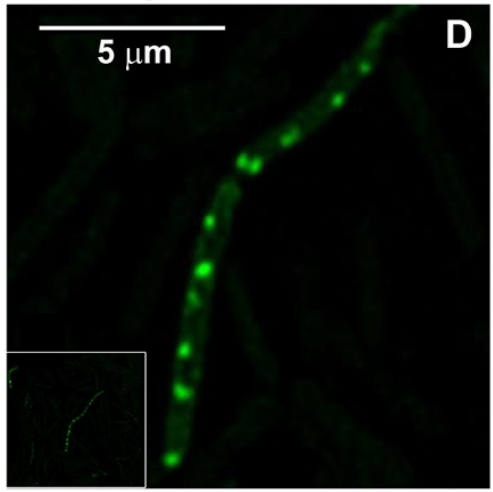

Figure 2 TthPAC subcellular location. Fluorescence confocal microscopy images were taken from exponential cultures of Tth HB27 $\triangle p a c$

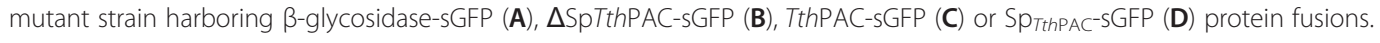




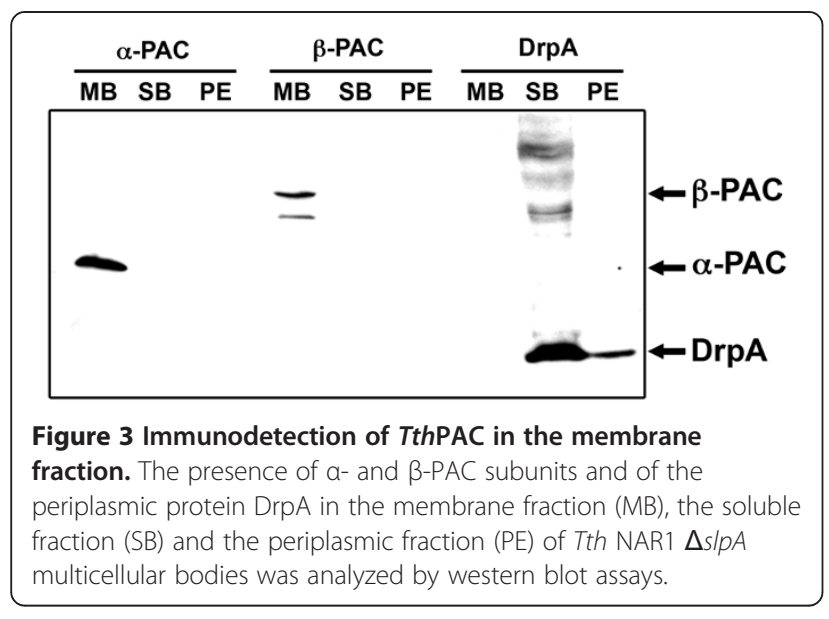

trypsin accessibility assays. They were carried out in the Tth NAR1 $\triangle s l p A$ mutant [13] in order to avoid impediments to the trypsin entrance. Additionally, EDTA was used to partially solubilize the outer membrane. Despite the fact that the TthPAC $\beta$-subunit was unaffected, the molecular weight of the $\alpha$-subunit was reduced after a 1-2 minute trypsin treatment (Figure 5). Immunodetection of Nqo1 under the same conditions showed less accessibility to degradation, suggesting that PAC was oriented towards the periplasmic space.

The high content of hydrophobic amino acids on the $\mathrm{N}$-terminal sequence of TthPAC suggests that this portion of the protein by itself could anchor the enzyme to the inner membrane of the bacteria. To evaluate this, we constructed a chimeric protein using the signal peptide of E. coli PGA and the TthPAC protein devoid of the first 32-amino acids from the N-terminal end. The

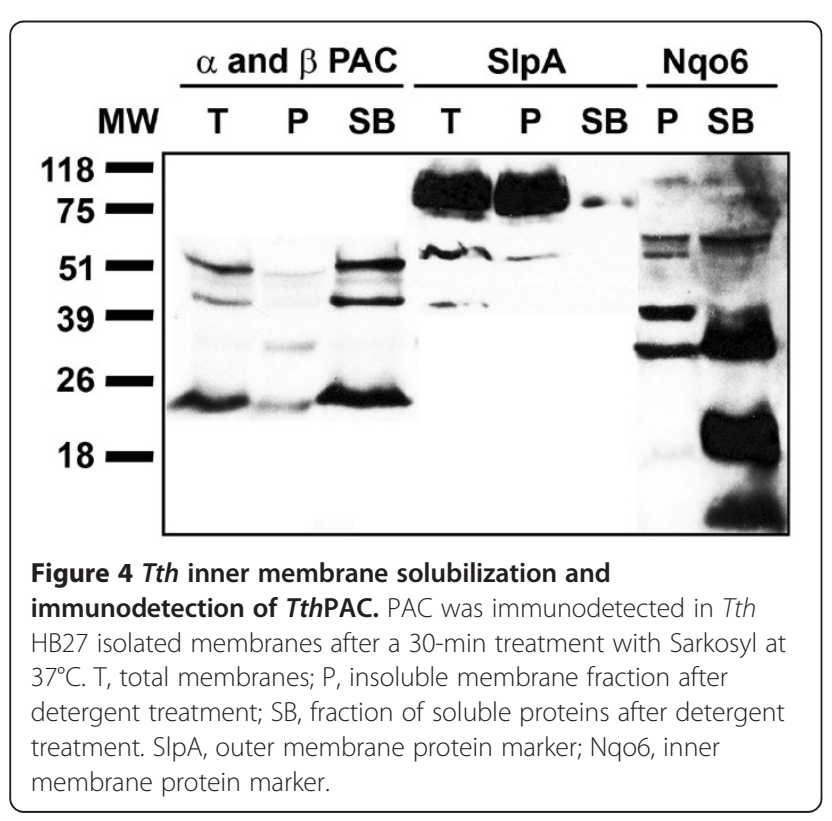

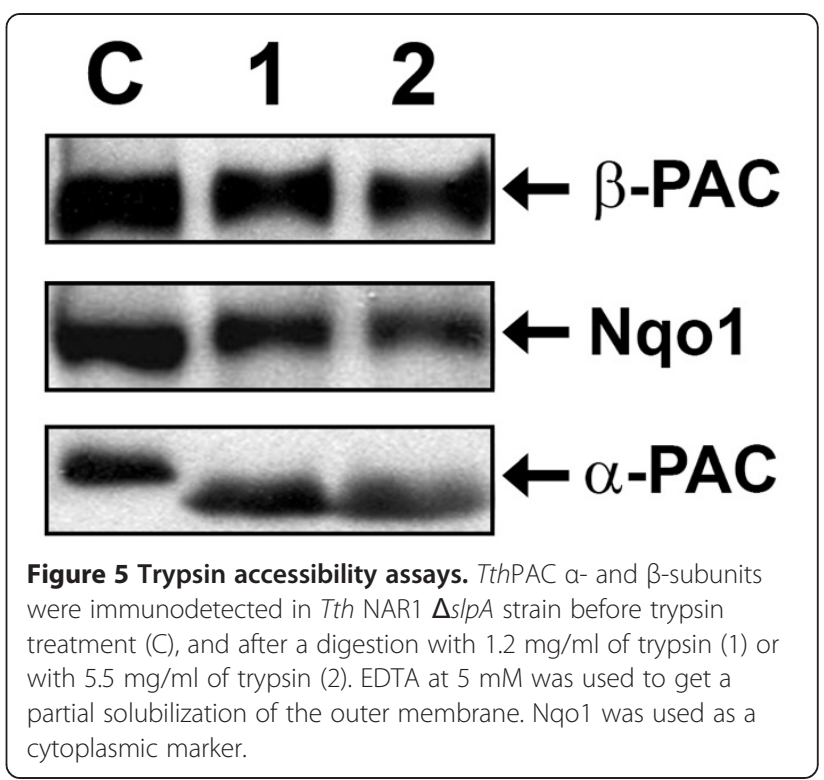

chimeric protein $\left(\mathrm{Sp}_{E c o}-\mathrm{PAC}_{T t h}\right)$ was expressed in a Tth $\Delta p a c$ mutant mainly as a soluble protein and was processed into $\alpha$ - and $\beta$-subunits (Figure 6). These data indicate that the $\mathrm{N}$-terminal sequence of $\mathrm{PAC}$ is the responsible for its anchoring to the membrane.

In mesophilic bacteria, PACs have been reported either as cytosolic or periplasmic proteins [10,11]. However, the data presented here show that TthPAC is attached to the external face of the cytoplasmic membrane, thus broadening the possible subcellular locations of the PACs to be studied hereafter. Based on the sGFP fusion experiments, we suggest that TthPAC is being directed to punctual secretion points of the cytosolic membrane, through the twin-arginine system (TAT), that has been shown to form foci near the cell poles in other bacteria

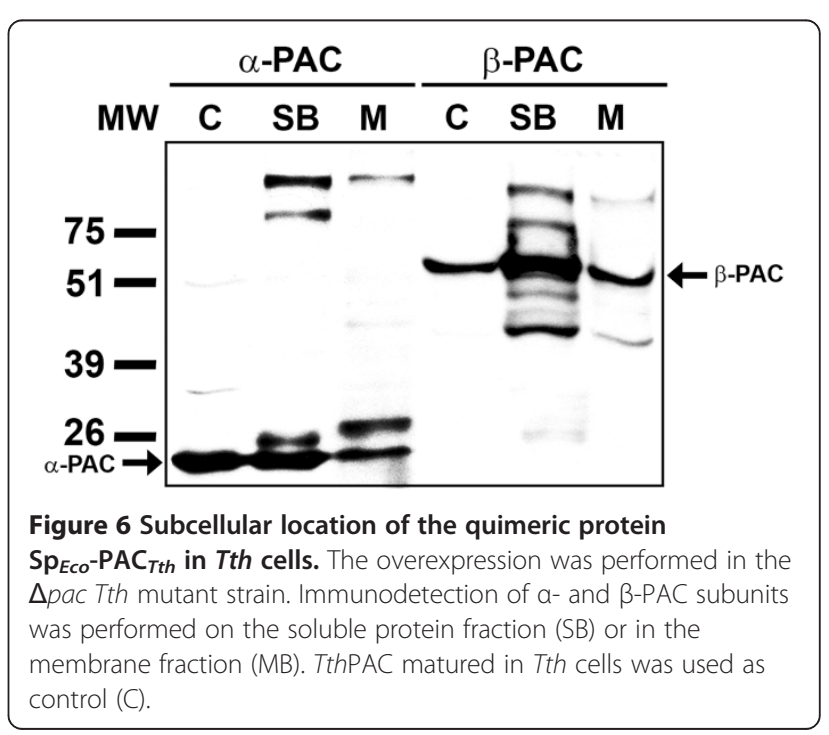


[18]. This is because sGFP folds in the cytoplasm [19] and the only secretion system that enables the transport of folded proteins is the TAT system. Also, the presence of two arginines in the N-terminal signal peptide of TthPAC protein supports this idea. In summary, we suggest TthPAC carries a non-cleavable TAT signal peptide that operates as a signal anchor domain. A similar case has been described for a Rieske Fe-S protein, whose TAT signal peptide is not processed but ultimately forms a transmembrane helix through the lipid bilayer [20]. Whether the membrane location of PACs is a feature that could be extended to other thermophilic bacteria is an issue to be elucidated.

\section{Homologous expression}

Due to the complexity of its processing, we first tried to overexpress the TthPAC protein directly in Tth cells. For this the pac gene was amplified by PCR, ligated to the pWUR112/77-1 [21] plasmid and overexpressed in a Tth $\Delta p a c$ mutant strain. As shown in Figure 7, from the total amount of pre-pro-PAC obtained only a fraction was auto-processed. Attempts to purify this mature TthPAC fraction proved difficult and resulted in low yields. Besides, unprocessed PAC as well as proteolytic polipeptides were found, indicating that the autoproteolytic processing of the pro-protein is compromised when an overexpression is performed, even in Tth cells (Figure 7). Because the efficiency of protein translocation through the TAT system is dependent on the amount of available transporter, the overproduction of TthPAC could have overwhelmed the secretion machinery, thus making the fraction of pre-pro-PAC that remained in the cytoplasm to mature improperly.

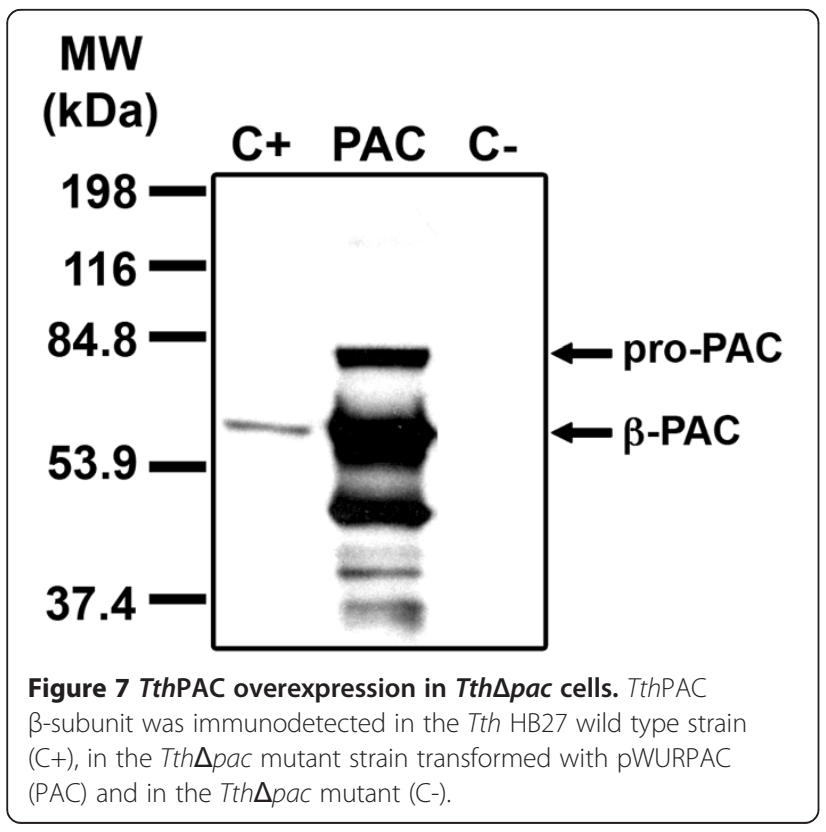

Heterologous expression of Tthpac in E. coli cells

Because of the results shown above, we tried to overexpress the TthPAC in E. coli. Since the N-terminal end of TthPAC turned out to be membrane anchored, two approaches were undertaken in order to manage TthPAC overexpression in E. coli cells. We constructed a 5 'shortened version of the pac gene $(\Delta \mathrm{Sp}$-Tthpac) and a fusion of the former with the leader sequence of the E. coli pga gene $\left(\mathrm{Sp}_{E c o}-p a c_{T t h}\right)$. The chimeric protein $\mathrm{Sp}_{E c o}-\mathrm{PAC}_{T t h}$ was efficiently translocated to the periplasmic space of $E$. coli, but the maturation of the protein into $\alpha$ - and $\beta$-subunits of the correct size failed [Additional file 1]. As translocation to another cell compartment often proves to be a bottleneck dependent on the efficiency and amount of available transporter, we focused on the expression of $\triangle \mathrm{Sp}-T$ thPAC, likely soluble into the cytoplasm of $E$. coli. Because a proper folding is necessary to achieve a successful pro-protein maturation, the effect of chaperone assistance was studied in the course of PAC overexpression. A selection of cytoplasmic chaperones, including trigger factor (TF), GroEL/ES, and DnaK/J-GrpE (TaKaRa Bio Inc.), were co-expressed with $\triangle \mathrm{Sp}$-TthPAC. Pro-PAC production and processing was evaluated by western blot, while TthPAC functionality was determined by measuring its enzymatic activity. As shown in Figure 8a, production of pro-PAC was enhanced by the presence of DnaK/J and GrpE and even more by the combination of TF and GroEL/ES. Also, in all conditions, a fraction of pro-PAC was processed into $\alpha$ - and $\beta$-subunits that showed electrophoretic migrations similar to the PAC subunits obtained from Tth cells, indicating that the posttranslational processing steps for TthPAC maturation can occur also in the cytoplasm of E. coli. However, when analyzing TthPAC activity in the same conditions we observed that both specific and volumetric activities in the culture without chaperone co-expression were similar to those observed in cultures with DnaK/J and GrpE or TF and GroEL/ES co-expression (Figure 8b). These results indicate that the production of mature TthPAC in E. coli cells can be increased through the co-expression of appropriate chaperone(s), but the fraction of TthPAC protein that is enzymatically active cannot be assumed from the total amount of TthPAC that is produced.

The use of cytoplasmic or periplasmic chaperones in the folding assistance of PACs overproduced in heterologous hosts has been widely reported [22-26]. As for TthPAC, TF and GroEL/ES proved to be the best choices at improving EcoPGA production [22]. However, in disagreement with the results reported by $\mathrm{Xu}$ et al. [22], we found that ThPAC activity in the presence of these chaperones was reduced when compared to the absence of folding modulator co-expression. We hypothesize that 


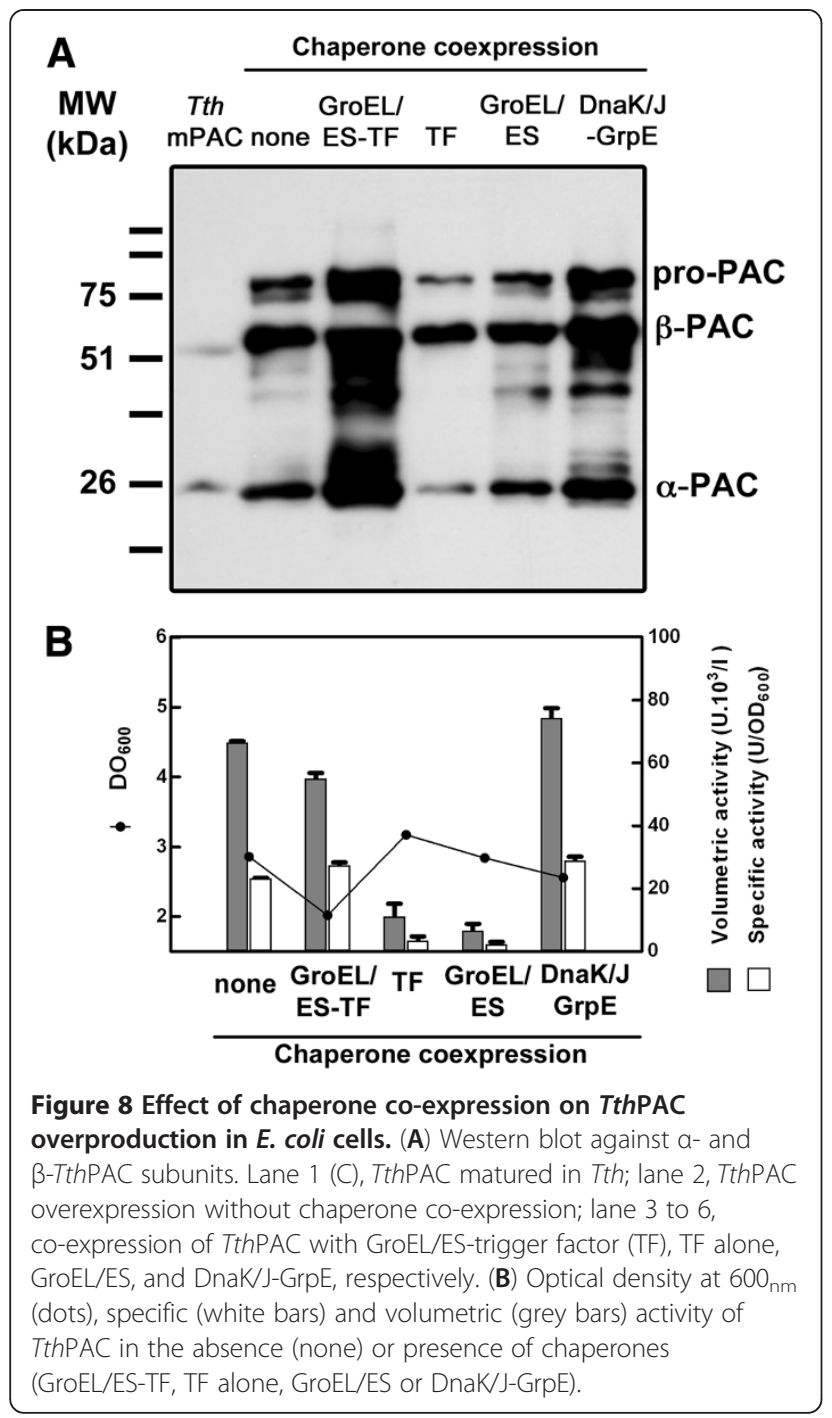

TthPAC remains attached to the chaperone after its folding assistance, so a proper TthPAC catalysis is prevented. Chaperone detaching experiments based on the use of ATP $/ \mathrm{Mg}^{+2}$ incubations were carried out, and a TthPAC release from GroEL/ES complex was observed [Additional file 2].

\section{Effect of $\mathrm{Ca}^{+2}$ on the production and maturation of TthPAC}

The crystal structure of EcoPGA (Protein Data Bank access number 1PNK) [27] and of the Brol mutant of Providencia rettgeri PGA [28], as well as analyses of induced coupled plasma-atomic emission spectroscopy on AfaePGA [29], revealed a tightly bound calcium ion in the structure of these three proteins. An amino acid sequence alignment of these PACs with the one from Tth showed that three of the six calcium co-ordinating residues identified in the above-mentioned PGAs are conserved in the TthPAC sequence [Additional file 3].
Calcium ions have been suggested to stabilize the PGA native state allowing its maturation to take place [30,31]. Indeed, the production of properly matured PGA proteins in E. coli cells has been improved in cultures supplemented with $\mathrm{CaCl}_{2}$ [32,33]. Hence, the influence of $\mathrm{Ca}^{+2}$ ions on the expression and maturation of TthPAC was tested. Increasing calcium concentrations up to $50 \mathrm{mM}$ were added to LB media from the beginning of the cultivation. Cell density, TthPAC expression and activity were analyzed, and results are summarized in Figure 9 . While cell growth was slightly modified by the presence of $\mathrm{Ca}^{+2}$, TthPAC specific and volumetric activity was markedly improved at $10 \mathrm{mM} \mathrm{Ca}{ }^{+2}$. Accordingly, western blot analysis of TthPAC expression and maturation in $E$. coli cells showed increased signals for $\alpha$ - and $\beta$-subunits along with $\mathrm{Ca}^{+2}$ concentration of $10 \mathrm{mM}$ (Figure 9). Regarding the auto-proteolytic processing of PAC, we observed that the size of both $\alpha$ - and $\beta$ subunits matched those of PAC obtained from Tth cells, suggesting a correct maturation of the pro-protein.

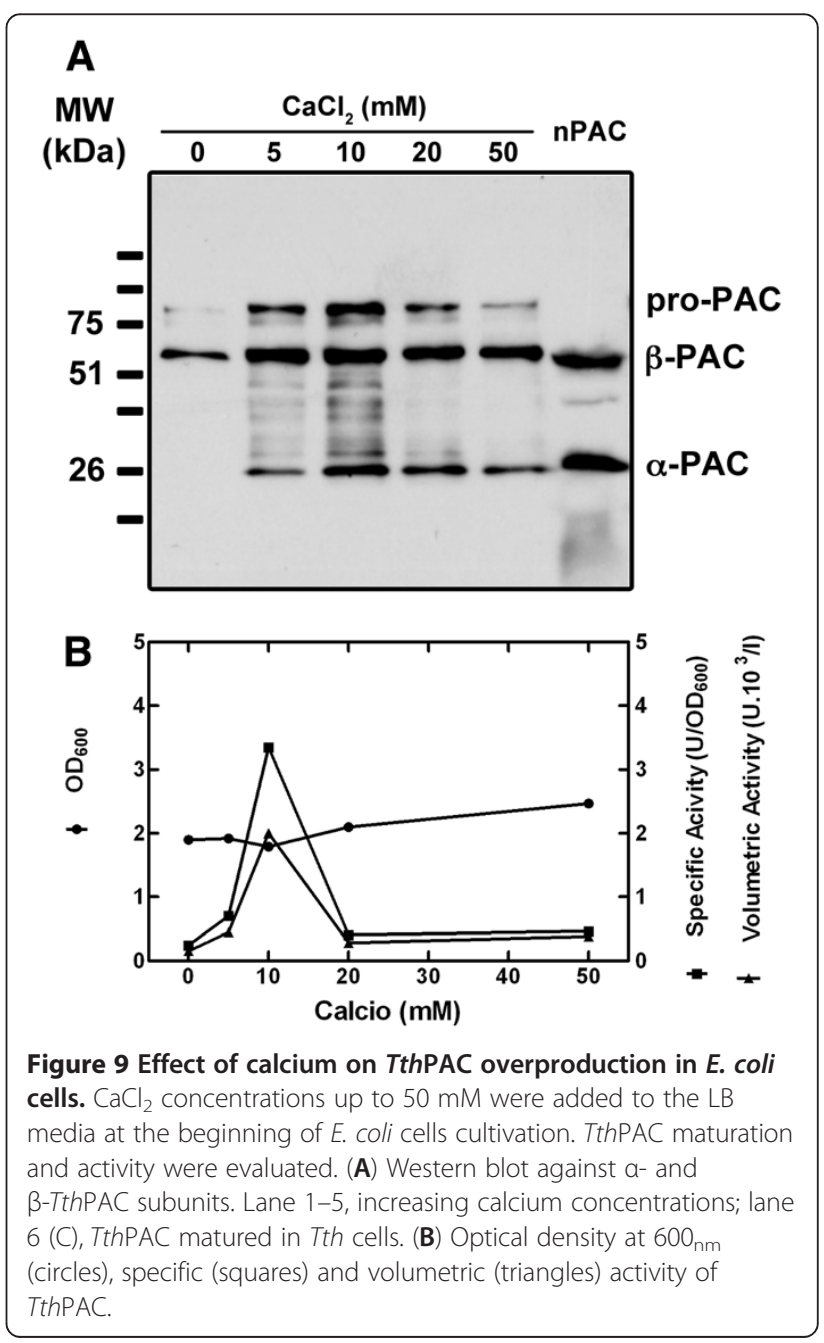


Calcium proved to be a critical factor when producing functional TthPAC, in the same way it was reported for the EcoPGA and AfaePGA [32,33]. The yield in active TthPAC could be increased 13-fold when culture media was supplemented with $10 \mathrm{mM}$ of $\mathrm{CaCl}_{2}$. From the results presented here we are able to suggest that calcium is part of the structure of TthPAC as already described for some mesophilic PGAs [27-29].

\section{Purification of recombinant TthPAC and evaluation of its maturation}

In order to confirm the correct maturation of Tth proPAC in E. coli, the recombinant protein was purified by IMAC chromatography (Figure 10). SDS-PAGE of the purified protein revealed two subunits of TthPAC with relative molecular masses $(\mathrm{Mr})$ of $26.4 \pm 1.0 \mathrm{kDa}$ ( $\alpha$-subunit) and $54.3 \pm 1.0 \mathrm{kDa}(\beta$-subunit) (Figure 10$)$. MALDI-TOF and LC-MS/MS analyses were performed on each subunit. As expected, the N-terminal residue of the $\beta$-subunit corresponded to the catalytic Ser256. The $\mathrm{C}$-terminus of the $\beta$-subunit was evident from the stop codon, whereas, the C-terminus of the $\alpha$-subunit depends on the length of the linker peptide cleaved from the pro-TthPAC. Since the $\alpha$-subunit was mapped up to residue Arg246, then the auto-processing maturation must have eliminated a 9-amino acid spacer-peptide [Additional file 3]. This is clearly a shorter linker peptide when compared to the 54- or 37-amino acid spacers of the mesophilic EcoPGA and AfaePGA, respectively [8,9]. However, since loops are likely the first structures that

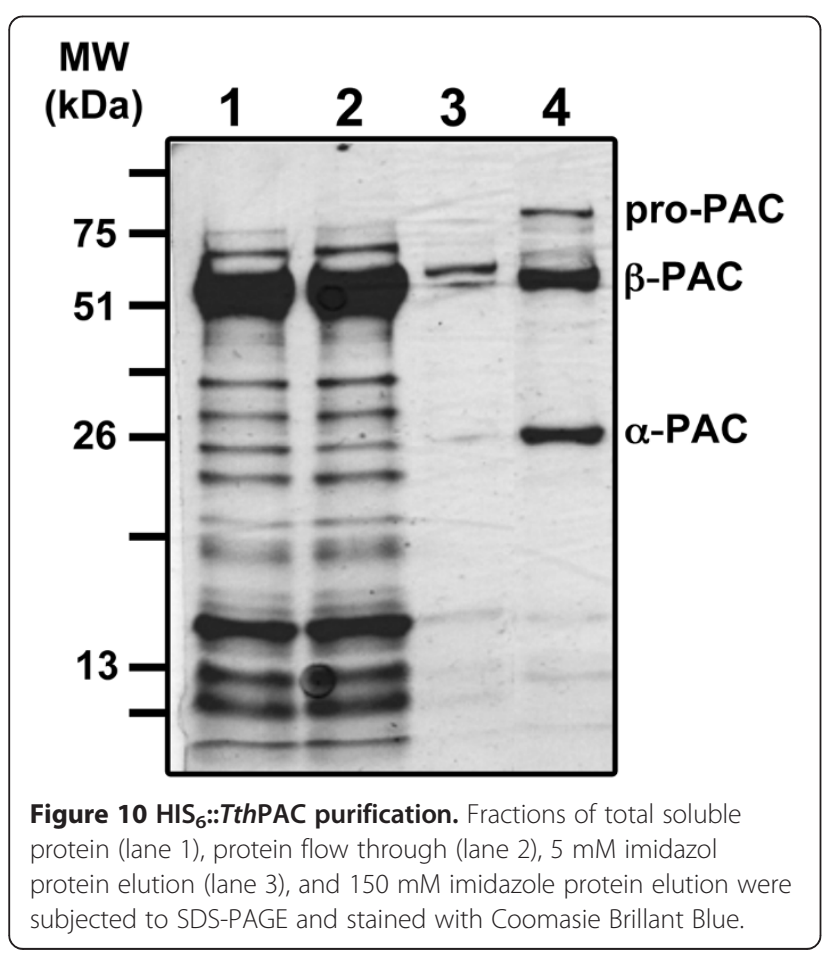

unfold during thermal denaturation, it is not surprising for a thermozyme to enhance its thermal stability through the shortening of loops [34]. Regarding the TthPAC $\alpha$-subunit, some disagreement between its molecular weight was experienced when producing TthPAC in Tth or E. coli cells. As shown in Figures 3, 4, TthPAC $\alpha$-subunit presented a $\mathrm{Mr}$ of aprox. $22 \mathrm{kDa}$ while the same subunit (with a 20-amino acid His-tag replacing the 32-residue signal peptide) processed in $E$. coli cells was aprox. $26 \mathrm{kDa}$ (Figures 8, 9, 10). Tth proteases, as most proteases from extremophilic bacteria, are serine proteases that are stable at high temperatures even in the presence of high concentrations of detergents and denaturing agents [35,36]. During cell lysis these proteases are normally activated, being probably responsible for the reduced size of the $\alpha$-subunit observed in Tth cells. Since TthPAC has a catalytic serine it is not possible to use serine-protease inhibitors during our protein purification protocols. Thus, the actual molecular weight of the $\alpha$-subunit cannot be deduced from the $\alpha$-PAC processed in E. coli nor from the one matured in Tth cells.

\section{Enzymatic characterization of TthPAC}

Recombinant TthPAC purified from E. coli cells was characterized biochemically. To examine its substrate selectivity, several aromatic and aliphatic penicillins, cephalosporins and homoserine-lactones were assayed for deacylating activity and results are summarized in Table 1. TthPAC was active only on penicillins. Penicillin K (octanoyl-penicillin) was the best substrate, with the highest specificity constant value (16.12 $\left.\mathrm{mM}^{-1} \cdot \mathrm{seg}^{-1}\right)$ compared to the other penicillins tested. TthPAC activity was assayed at different $\mathrm{pH}$ values. In contrast to what is usually described for PAC enzymes we observed an optimal pH of 4.0 [Additional file 4]. Also, the TthPAC enzymatic activity was assayed in a range from 57.5 to $82.5^{\circ} \mathrm{C}$. The highest hydrolytic activity of TthPAC was achieved at $75^{\circ} \mathrm{C}$ (Figure 11). The preference for hydrophobic acyl-chain penicillins has been described previously for the PAC of the actinomycete Streptomyces lavendulae and the aculeacin A acylase from Actinoplanes utahensis [37,38] (see Additional file 5 for a straightforward comparison). In fact, a new subfamily of penicillin $\mathrm{K}$ acylases (PKAs) has been proposed to classify these two enzymes [38]. Clearly, from the results presented here, TthPAC should be included in this subfamily and thus be renamed TthPKA. Another common feature between $A$. utahensis PKA and TthPKA is that they are both thermostable enzymes with an optimum reaction temperature of aprox. $75^{\circ} \mathrm{C}$. However, while the half-life of the $A$. utahensis acylase at $65^{\circ} \mathrm{C}$ was calculated to be $477 \mathrm{~min}$ [38], TthPAC exhibited a halflife of $552 \mathrm{~min} .(9.2 \mathrm{~h})$ at $75^{\circ} \mathrm{C}$ [Additional file 6]. 
Table 1 Kinetic parameters of TthPAC for the hydrolysis of different substrates

\begin{tabular}{lcccc}
\hline Substrate & R (acyl chain) & $\mathbf{K}_{\mathbf{m}}(\mathbf{m M})$ & $\mathbf{k}_{\text {cat }}$ & $\mathbf{k}_{\text {cat }} / \mathbf{K}_{\mathbf{m}}$ \\
\hline Penicillin K & Octanoyl & $0.32 \pm 0.05$ & $5.16 \pm 0.13$ & $1.16 \pm 0.06$ \\
Penicillin dihydro F & Hexanoyl & $0.98 \pm 0.22$ & $0.90 \pm 0.03$ & 1.49 \\
Penicillin F & hexenoyl & $0.94 \pm 0.18$ & $0.57 \pm 0.01$ & 0.96 \\
Penicillin V & Phenoxyacetyl & $0.74 \pm 0.11$ & Approx. 4.10 & Approx. 1.10-4 \\
Penicillin G & Phenylacetyl & Approx. 2.90 & nd & nd \\
Glutaryl-7-ACA & Glutaryl & nd & nd & nd \\
Cephalosporin C & 7-aminoadipyl & nd & nd & nd \\
C4-HSL & Butiryl & nd & nd & nd \\
C8-HSL & Octanoyl & & &
\end{tabular}

nd: no detectable activity.

While the actinomycetal PKAs share $40 \%$ identity, TthPAC has only between $16-18 \%$ of identical residues with the former proteins. However when comparing the amino acid sequence of these three proteins with the ones of PACs with aromatic active centers (such as EcoPGA, AfaePGA, P. rettgeri PGA), some replacements that could explain the preference for an aliphatic or aromatic penicillin become evident. Two of the Phe identified as stabilizing residues of the phenylacetyl moiety of penicillin G in EcoPGA ( $\alpha 172$ and $\beta 57$ ) [27], are replaced by Ser/Gly and Ile, respectively, in PKAs [Additional file 3].

\section{Conclusions}

A PAC enzyme from the extreme thermophile Tth HB27 strain was identified in the outer side of the cytoplasmic membrane. This is the first reported PAC from a extreme thermophile and owing to its potential use as a thermostable biocatalyst, an N-terminal 32-amino acid deletion version of TthPAC was successfully

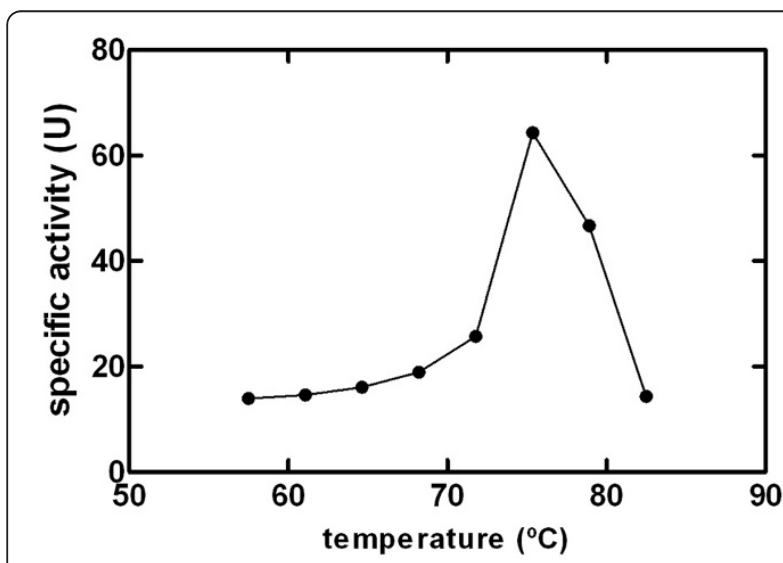

Figure 11 Optimum reaction temperature of $\mathrm{HIS}_{6}::$ TthPAC. The TthPAC enzymatic activity was assayed in $20 \mathrm{mM} \mathrm{MES} \mathrm{pH} \mathrm{5.5,} \mathrm{in} \mathrm{the}$ presence of $0.5 \mathrm{mM}$ PenK and in a temperature range from 57.5 to $82.5^{\circ} \mathrm{C}$. overexpressed in E. coli cells using chaperone coexpression and calcium supplementation of the culture medium in order to enhance productivity and activity. The recombinant protein was purified and the maturation of the precursor in the cytoplasm of $E$. coli leading to an active enzyme was confirmed by MALDI-TOF analysis of the individual subunits. In the light of these data, a similar maturation process and mechanistic features as EcoPAC (N-terminal nucleophile Ser, structural calcium, activity-modulating linker peptide) can be hypothesized for this enzyme. Enzymatic characterization of TthPAC was performed and its preference for aliphatic-chain penicillins was established, in good correlation with the aromatic for aliphatic substitutions found in multiple alignments for well-characterized. Industrial preparations of PenG obtained as bulk materials by fermentation contain up to $3 \%$ aliphatic penicillins, which cannot be hydrolyzed by PenG acylases and represent a significant amount in large-scale operations [37]. These "impurities" can now be hydrolyzed by PKAs, such as the one described in this work. Furthermore, penicillin acylases are not limited to penicillin hydrolysis and have a wide substrate specificity finding uses in other biocatalytic reactions, such as amide and ester formation under kinetic control or kinetic resolutions of amides [39]. TthPAC showed an optimum reaction temperature of $75^{\circ} \mathrm{C}$ and thermal stability assays confirm that this enzyme clearly surpasses the stability of all other reported (native) acylases up to date, making it an interesting addition to the existing biocatalytic toolbox.

\section{Methods}

Materials and bacterial strains

All reagents used were of analytical grade and were purchased from Sigma (st. Louis, MO, USA) or Merck (Darmstadt, Germany). Penicillin G, V, K, F and dihydroF were kindly provided by Antibioticos S.A. (León, Spain). Tth $\Delta p a c$ is a knockout in the pac gene 
(NCBI accession number TTC1972) derived from Tth HB27 strain. Tth $\triangle \operatorname{slpA}$ is a knockout in the $\operatorname{slp} A$ gene derived from Tth NAR1 strain [13]. E. coli DH5 $\alpha$ [F- Ф80lacZ $\Delta$ M15 $\Delta$ (lacZYA-argF) U169 recA1 endA1 hsdR17 (rK-, mK+) phoA supE44 $\lambda-$ thi-1 gyrA96 relA1] was used for subcloning steps and E. coli BL21 (DE3) [F- ompT hsdSB(rB-, mB-) gal dcm (DE3)] was used as the host for recombinant protein expression.

\section{Plasmid constructions}

All the primers used in this work are listed in [Additional file 7: Table S2]. In order to produce antibodies against the $\alpha$ - and $\beta$-subunits of PAC, each subunit was amplified from Tth HB27 genome using the primers $\alpha \mathrm{NdeIFw}$ and $\alpha E c o R v$ for the $\alpha$-subunit and $\beta$ NdeIFw and $\beta E$ coRv for the $\beta$-subunit. The DNA fragments were cloned into the pET28b + plasmid between the NdeI and EcoRI restriction sites, yielding plasmids pET28 $\alpha$ PAC and pET28ßPAC. For the expression of the fusions with sGFP [12], Tthpac leader sequence, the entire Tthpac gene, Tthpac devoid of its leader sequence and Tth $\beta$-glycosidase codifying gene (NCBI accession number TTP0042) were amplified from Tth HB27 genome using the pairs of primers lsFw/lsRv, pacFw/pacRv, $\Delta$ SppacFw /pacRv, and $\beta$ glyFw/BglyRv. The gene fusions were cloned into the plasmid pMKPnqosGFP [4]. For the expression of the chimeric protein $\mathrm{Sp}_{E c o}-\mathrm{PAC}_{T t h}$, the codifying sequence for the signal peptide of E. coli PGA was amplified with the primers EcoFw and EcoRv. The Tth pac gene devoid of its leader sequence was amplified from Tth HB27 genome with the primers $\triangle$ SppacFw and $\Delta$ SppacRv. The gene fusion was assembled by overlap extension PCR and ligated to the pMKPnqo expression plasmid. For the homologous expression of TthPAC, the pac gene was amplified from Tth HB27 genome with the primers pac $2 \mathrm{Fw}$ and pac2Rv. The gene was ligated to the pWUR112/77-1 [21] expression plasmid and the construction was named pWURPAC. For the heterologous expression of Tthpac, the $\Delta \mathrm{Sppac} 2 \mathrm{Fw}$ primer and the $\triangle$ Sppac2Rv primer were used in a PCR reaction for the amplification of a $2223 \mathrm{bp}$ fragment corresponding to the Tthpac gene without the 5' 96-nucleotide codifying sequence. The amplified gene was cloned into the pET28a plasmid between the NdeI and EcoRI restriction sites, yielding plasmid pET28a- $\triangle \mathrm{SpPAC}$. The construction was then transformed into $E$. coli $\mathrm{DH} 5 \alpha$ competent cells. Plasmids were extracted and their inserts were sequenced to confirm the absence of mutations in Tthpac gene.

\section{Confocal microscopy}

Fluorescence microscopy was performed using a Zeiss Inverted LSM510 confocal microscope. Z-stacks were obtained using a Zeiss $100 x / 1.3$ oil Plan-Neofluar objective lens and parameters appropriate to comply with the Nyquist criteria for image sampling. Images were subjected to linear deconvolution using the Huygens System 2.2 software (Scientific Volume Imaging B. V., Hilversum. the Netherlands). Adobe Photoshop and Image J (Wayne Rasband, NIH, USA) were used for final assembly of the images. For sGFP fusion experiments, Tth HB27 strain was transformed with each one of the sGFP fusions ( $\beta$-glycosidase-sGFP, $\Delta$ SpTthPAC-sGFP, TthPAC-sGFP and $\mathrm{Sp}_{\text {TthPAC-SGFP) and was }}$ grown aerobically in TB liquid media (Ramirez-Arcos et al., 1998) at $70^{\circ} \mathrm{C}$ with mild shaking $(150 \mathrm{rpm})$ up to an $\mathrm{OD}_{550}$ of 0.2-0.4 before cell harvesting by low-speed centrifugation (3,000 xg, $5 \mathrm{~min}$ ). Mowiol was added after washing the cells with Milli-Q water.

\section{Isolation of the membrane fraction of Tth cells}

Bacteria in mid-log growth phase were harvested by centrifugation at $5000 \mathrm{xg}$ for $5 \mathrm{~min}$ at room temperature. The pellet was washed in TE $1 \mathrm{X}$ (Tris $10 \mathrm{mM} \mathrm{pH} \mathrm{8,}$ EDTA $1 \mathrm{mM}$ ) buffer and resuspended in TE. Cells were disrupted in a LABSONIC U sonicator (B. Braun) (2 times 30 seconds -1 minute). Intact cells were removed by centrifugation at $5000 x \mathrm{~g}$ for $5 \mathrm{~min}$. The supernatant was ultracentrifuged $30 \mathrm{~min}$ at 201,240 $\mathrm{xg}$ at $4^{\circ} \mathrm{C}$ in a Beckman TL-100. The pellet was washed in $10 \mathrm{mM}$ Tris- $\mathrm{HCl} \mathrm{pH} 7.5$ and was centrifuged again in the same conditions. The final pellet corresponded to the membrane fraction.

\section{Selective solubilization of membrane components}

Selective solubilization of the cytoplasmic membrane by non-ionic or weakly-ionic detergents is a widely used method to separate the inner and outer membrane components in Gram negative bacteria [14-17]. The membrane fraction was resuspended in $10 \mathrm{mM}$ Tris$\mathrm{HCl} \mathrm{pH} 7.5$ and $1 \%$ Triton X-100 or $1 \%$ Sarkosyl and incubated for $30 \mathrm{~min}$ at $37^{\circ} \mathrm{C}$. Samples were then ultracentrifuged $30 \mathrm{~min}$ at 201,240 $\mathrm{xg}$ and $4^{\circ} \mathrm{C}$. Supernatant was stored and the pellet was washed once again in the same buffer and centrifuged in the same conditions. Both fractions were subjected to SDS-PAGE and immunodetection of TthPAC subunits.

\section{Trypsin accessibility}

Tth NAR1 $\triangle \operatorname{slpA}$ strain was grown at $70^{\circ} \mathrm{C}$ under aerobic conditions up to saturation. The bacteria were harvested by centrifugation at $5000 x \mathrm{~g}$ for $5 \mathrm{~min}$ at room temperature, washed once with $10 \mathrm{mM}$ Tris- $\mathrm{HCl} \mathrm{pH}$ 8.0 , and the resulting pellet was resuspended in the same buffer up to a final cell concentration of $10^{10}$ cells $/ \mathrm{ml}$. Trypsin treatment was carried out using two different concentrations of enzyme at $37^{\circ} \mathrm{C}$ in the presence or 
absence of 5 or $10 \mathrm{mM}$ EDTA. TthPAC integrity was analyzed by western blot.

\section{Homologous expression}

The Tth HB27 $\Delta p a c$ mutant strain was transformed with the plasmid pWUR112/77-1 [21] carring the pac gene (pWURPAC) and was plated onto TB (Ramírez-Arcos et al., 1998) agar with bleomycin [21]. The constitutive expression of PAC was carried out growing the clones aerobically in TB liquid media (Ramírez-Arcos et al., 1998) with bleomycin at $70^{\circ} \mathrm{C}$ and $150 \mathrm{rpm}$ until saturation. Cells were harvested by centrifugation at 4,000 $\times$ $\mathrm{g}$ and $4^{\circ} \mathrm{C}$ for $15 \mathrm{~min}$. Cell pellets were resuspended in $50 \mathrm{mM}$ Tris buffer $\mathrm{pH} 7.5$ and $50 \mathrm{mM} \mathrm{NaCl}$ and disrupted by sonication on ice bath ( 2 rounds of 45 secs), using a sonicator LABSONIC U (B. Braun).

\section{Heterologous expression and purification of PAC}

E. coli BL21(DE3) strain was transformed with the plasmid pET28a carring the $\triangle$ Sp-Tthpac gene (pET28a$\triangle \mathrm{spPAC}$ ) and was plated on LB agar with kanamycin $(30 \mu \mathrm{g} \mathrm{mL}-1)$. The strain E. coli BL21(DE3) pET28a$\triangle \mathrm{spPAC}$ was then transformed with the vectors pGTf2, pTf16, pGro7 or pKJE7 (Takara Bio Inc), carrying the genes for GroEL-GroES, Trigger factor, GrpE and DnaKDnaJ chaperone systems. Transformants were plated onto LB agar containing kanamycin $(30 \mu \mathrm{g} \mathrm{mL}-1)$ and chloramphenicol $(30 \mu \mathrm{g} \mathrm{mL}-1)$. Both transformations were based on the calcium temperature shock method.

The inoculums for batch protein production were prepared by overnight cultivation of the selected clone in $100 \mathrm{~mL}$ shake flaks with $20 \mathrm{ml}$ of $\mathrm{LB}$ medium at $37^{\circ} \mathrm{C}$. For protein production $1.5 \mathrm{~mL}$ of the corresponding inoculum culture was transferred to $150 \mathrm{~mL}$ of fresh $\mathrm{LB}$ medium supplemented with $10 \mathrm{mM} \mathrm{CaCl}_{2}$, and containing 0.5 g. $\mathrm{L}^{-1}$ of $\mathrm{L}$-arabinose for chaperone induction. Cells were cultivated at $37^{\circ} \mathrm{C}$ and $200 \mathrm{rpm}$ until they reached the TthPAC over-expression induction point, corresponding to an $\mathrm{OD}_{600} \approx 0.6 \pm 0.5$. Induction was performed by addition of IPTG (isopropyl- $\beta$ - $D$ thiogalactopyranoside) to a final concentration of $1 \mathrm{mM}$, and cultivation was continued for 17 hours at $22^{\circ} \mathrm{C}$ and 200 $\mathrm{rpm}$. Cells were harvested by centrifugation $(4,000 \times \mathrm{g}$ for $15 \mathrm{~min}$ ) at $4^{\circ} \mathrm{C}$. Cell pellets were resuspended in 10 $\mathrm{mL}$ of lysis buffer $(50 \mathrm{mM}$ sodium phosphate $\mathrm{pH} 7.0$, $300 \mathrm{mM} \mathrm{NaCl}$ ) and disrupted by sonication on ice bath ( 3 rounds of $10 \mathrm{~min}, 0.6$ pulse and $40 \%$ power), using a sonicator LABSONIC U (B. Braun). Soluble and insoluble protein fractions were separated by centrifugation at $12,000 \times \mathrm{g}$ for $15 \mathrm{~min}$ at $4^{\circ} \mathrm{C}$. The supernatant containing the His-tagged protein was partially purified from thermolabile $E$. coli proteins by a heat-shock treatment of $20 \mathrm{~min}$ at $65^{\circ} \mathrm{C}$. Thermostable proteins were recovered from the supernatant after centrifugation
$(12,000 \times \mathrm{g}$ for $30 \mathrm{~min})$ at $4^{\circ} \mathrm{C}$, and subjected to IMAC chromatography using a Talon Cell-through resin (BD Biosciences) previously equilibrated with lysis buffer. The column was washed once with 1 volume of the lysis buffer. The His-tagged protein was eluted with $150 \mathrm{mM}$ imidazole, diafiltrated and concentrated with Amicon Ultra-15 $10 \mathrm{kDa}$ centrifugal devices ((Millipore) using $50 \mathrm{mM}$ sodium phosphate $\mathrm{pH}$ 7.0, $5 \mathrm{mM} \mathrm{NaCl}, 0.5 \mathrm{mM}$ $\mathrm{CaCl}_{2}$, and stored at $-20^{\circ} \mathrm{C}$ until use. The use of stabilizing additives like polyols was avoided because we observed interference with components of the reaction mixture. Protein content was determined using the BioRad protein assay dye reagent concentrate (Bio-Rad, USA) with bovine serum albumin as standard. Samples for SDS-PAGE separation were prepared in $5 \times$ SDSPAGE loading buffer and heated for $5 \mathrm{~min}$ at $95^{\circ} \mathrm{C}$. Electrophoresis of protein samples was done with $12 \%(\mathrm{w} / \mathrm{v})$ SDS-PAGE and the gel was stained with Coomassie Brilliant Blue R-250. Identical samples were electroblotted on PVDF membranes and incubated with polyclonal rabbit antibodies against the $\alpha$ - and $\beta$-subunit of TthPAC, and later with an alkaline phosphataseconjugated goat anti-rabbit antibody.

\section{MALDI-TOF/MS analysis}

Metal affinity purified $\mathrm{His}_{6}:: \Delta \mathrm{Sp} T$ thPAC was subjected to SDS-PAGE on $12 \%$ polyacrylamide gels and the proteins were stained with Coomassie Brillant Blue R-250 solution. The polypeptide bands corresponding to $\alpha$ and $\beta$-subunits of TthPAC protein were excised from the gel and subjected to MALDI-TOF mass spectrometer analysis. The peptide identification by LC/MS/MS analysis was carried out in the 'CBMSO Protein Chemistry Facility', a member of ProteoRed network.

\section{Determination of TthPAC enzymatic activity and thermal stability}

Fluorescamine was used to follow the kinetics of TthPAC against penicillins, cephalosporins or homoserine-lactones, through the reaction with the primary amine group of the corresponding reaction products. Aliquots of 40 microliter of reaction mixture were taken at regular intervals and were immediately frozen in dry ice after which $140 \mu \mathrm{l}$ of $200 \mathrm{mM}$ acetate buffer $\mathrm{pH} 4.5$ and $20 \mu \mathrm{l}$ of $1 \mathrm{mg} \cdot \mathrm{mL}^{-1}$ fluorescamine in acetone were added. After a 60-min incubation at room temperature fluorescence was determined (Exc. $380 \mathrm{~nm}$ - Em. $530 \mathrm{~nm}$ ) in a FLUOStar OPTIMA plate reader (BMG LabTech). All experiments were performed in duplicate, and the effect of non-enzymatic hydrolysis of substrates was subtracted. Substrate selectivity was analyzed using penicillin K, F, DHF, V or G, glutaryl-7 amino cephalosporanic acid (glutaryl-7ACA), cephalosporine $\mathrm{C}$, and butyryl- or octanoyl-homoserine lactones (C4- or C8- 
HSL, respectively). Kinetic parameters $V_{\max }$ and $K_{\mathrm{m}}$ were determined by measuring the initial rate of hydrolysis on a range of substrate concentrations from 0.1 to $50 \mathrm{mM}$, using $0.8-2.0 \mu \mathrm{g}$ of purified enzyme in $20 \mathrm{mM}$ MES pH 5.5 for up to $1 \mathrm{~h}$ at $65^{\circ} \mathrm{C}$. Optimum $\mathrm{pH}$ for the hydrolysis of $2.5 \mathrm{mM}$ penicillin $\mathrm{K}$ was assayed at $65^{\circ} \mathrm{C}$ in $20 \mathrm{mM}$ Britton-Robinson buffer at $\mathrm{pH} \mathrm{3,} \mathrm{4,} \mathrm{5,} \mathrm{6,}$ 7,8 or 9 [40]. The temperature giving maximum penicillin $\mathrm{K}$ hydrolysis was determined by incubating $0.2 \mu \mathrm{g}$ of enzyme with $0.5 \mathrm{mM}$ of penicillin $\mathrm{K}$ in $20 \mathrm{mM}$ MES pH 5.5 , in a reaction volume of $50 \mu \mathrm{l}$ at various temperatures within the range of $57.5^{\circ} \mathrm{C}$ to $82.5^{\circ} \mathrm{C}$. The reaction was carried out in a 96-well PCR plate on a Thermal Cycler (Bio-Rad) running in gradient mode. After the reaction, the tubes were immediately chilled on ice. Thermal stability was determined incubating $0.08 \mathrm{mg} / \mathrm{ml}$ solutions of purified TthPAC in $50 \mathrm{mM}$ phosphate buffer $\mathrm{pH} 7.5$ at 65 and $75^{\circ} \mathrm{C}$ and measuring the residual hydrolytic activity at regular intervals as detailed above using $5 \mathrm{mM}$ penicillin $\mathrm{K}$ as substrate.

\section{Additional files}

Additional file 1: Heterologous expression of the chimeric protein $\mathrm{Sp}_{E c o}-\mathrm{PAC}_{T \text { th }}$ in E. coli cells. TthPAC a- and $\beta$-subunit were immunodetected in the cytoplasmic fraction (upper and middle panels) and in the periplasmic fraction (lower pannel) of E. coli cells from BL21 strain(1, A and G); Rosetta-gami2 strain (2, B and H); BL21 strain co-expressing GroEL/ES and trigger factor ( $3, C$ and I), trigger factor alone (4, D and J), GroEL/ES (5, E and K) or DnaK/J and GrpE (6, F and L). Protein samples were partially purified $(+)$ or not $(-)$ from $E$. coli thermolabile proteins by a 20 min-incubation at $65^{\circ} \mathrm{C}$ and later centrifugation.

Additional file 2: Chaperone elimination after co-expression with HIS $_{6}:: T t h P A C$. TthPAC was co-expressed with GroEL/ES in E. coli BL21 cells. Total soluble protein fraction was incubated in the absence (lanes 1-4) or in the presence of $5 \mathrm{mM} \mathrm{ATP} / 10 \mathrm{mM} \mathrm{Cl}_{2} \mathrm{Mg}$ (lanes 5-8) [41] for $2 \mathrm{~h}$ at $4^{\circ} \mathrm{C}$. In order to separate the TthPAC from the detached GroEL/ES a 0-, 30-, 45- or 60 -min incubation at $65^{\circ} \mathrm{C}$ and later centrifugation was performed. Immunodetection of $\beta$-TthPAC shows that the mobility of this subunit (aprox. $60 \mathrm{kDa}$ ) is reduced when GroEL is eliminated (also 60 kDa)

Additional file 3: Sequence alignment of PKAs and characterized PGAs. TthPKA, Thermus thermophilus HB27 PKA [TTC1972]; AutaPKA, Actinoplanes utahensis PKA [P29958]; SlavPKA, Streptomyces lavendulae PKA [AY611030]; EcoPGA, Escherichia coli PGA [P06875]; AfaePGA, Alcaligenes faecalis [ADD11517]; PretPGA, Providencia rettgeri PGA [AAP86197]; KcitPGA, Kluyvera citrophila [AAA25047]. Accession numbers to public databases are provided between brackets. TthPAC a- and $\beta$-subunit extensions determined by MALDI-TOF analysis are shown with a red and blue arrow, respectively. Residues involved in calcium co-ordination are shown in yellow and identified with a letter "a" below the corresponding alignment column. Penicillin G-binding residues that differ within PGAs and PKAs are shown in red and blue color, respectively, and are identified with a letter "b" below the corresponding alignment column.

Additional file 4: Optimum pH of $\mathrm{HIS}_{6}:$ TthPAC. The TthPAC enzymatic activity was assayed at $65^{\circ} \mathrm{C}$ in the presence of $2.5 \mathrm{mM}$ PenK and in $20 \mathrm{mM}$ Britton-Robinson buffer at $\mathrm{pH} 3,4,5,6,7,8$ or 9.

Additional file 5: Comparison of the kinetic data of TthPAC with other penicillin acylases. Data were measured at $40^{\circ} \mathrm{C}$ unless otherwise stated.
Additional file 6: Thermal inactivation course of TthPAC. Solutions containing $0.08 \mathrm{mg} / \mathrm{ml}$ of purified TthPAC were incubated in $50 \mathrm{mM}$ phosphate buffer $\mathrm{pH} 7.5$ at 65 and $75^{\circ} \mathrm{C}$. The residual hydrolytic activity was determined using $5 \mathrm{mM}$ penicillin $\mathrm{K}$ as substrate.

Additional file 7: Table S2. Primers used in this work.

\section{Abbreviations}

Tth: Thermus themophilus; PAC: penicillin acylase; PGA: penicillin G acylase; PKA: penicillin K acylase; 6-APA: 6 -aminopenicillanic acid; $t_{1 / 2}$ : half-life; ORF: open reading frame; sGFP: superfolder green fluorescent protein; Sp: signal peptide; SIpA: S-layer protein; DrpA: nitrate respiration system regulatory protein; TAT: twin arginine transporter; TF: trigger factor.

\section{Competing interests}

The authors declare financial competing interests. The contents of this manuscript have been partially patented by the authors' institution (application number P201230729).

\section{Authors' contributions}

LLT carried out the cloning and the heterologous expression of $\triangle$ SpTthPAC and $S P_{E C O}-P A C_{T t h}$, the purification and the biochemical characterization of PAC protein, and drafted the manuscript. ACC participated in the heterologous expression of both proteins. EF performed the PAC subcellular location experiments, the trypsine accessibility assays, the PAC homologous expression and contributed to draft the manuscript. AH drafted the manuscript, and $\mathrm{AH}$ and JB critically revised and corrected the manuscript. All authors read and approved the final manuscript.

\section{Acknowledgements}

L.T., A.H. and J.B. acknowledge funding from the Spanish Ministry of Science (grants CIT 010000-2009-29, RyC2006-02441) and an institutional grant from Fundación Ramón Areces to CBMSO. A.H. and J.B. are thankful to M.J. de Soto and E. Sánchez for their assistance. We also acknowledge support of the publication fee by the CSIC Open Access Publication Support Initiative through its Unit of Information Resources for Research (URICI).

Received: 17 May 2012 Accepted: 3 August 2012

Published: 9 August 2012

\section{References}

1. Yoon J, Oh B, Kim K, Park J, Han D, Kim KK, Cha S-S, Lee D, Kim Y: A Bound Water Molecule Is Crucial in Initiating Autocatalytic Precursor Activation in an N-terminal Hydrolase. J Biol Chem 2004, 279:341-347.

2. Cai G, Zhu S, Yang S, Zhao G, Jiang W: Cloning, Overexpression, and Characterization of a Novel Thermostable Penicillin G Acylase from Achromobacter xylosoxidans: Probing the Molecular Basis for Its High Thermostability. Appl Environ Microbiol 2004, 70:2764-2770.

3. Rajendhran J, Gunasekaran P: Molecular cloning and characterization of thermostable [beta]-lactam acylase with broad substrate specificity from Bacillus badius. J Biosci Bioeng 2007, 103:457-463.

4. Cava F, Hidalgo A, Berenguer J: Thermus thermophilus as biological model. Extremophiles 2009, 13:213-231.

5. Jenney FE Jr, Adams MW: The impact of extremophiles on structural genomics (and vice versa). Extremophiles 2008, 12:39-50.

6. Koma D, Sawai T, Harayama S, Kino K: Overexpression of the genes from thermophiles in $<\mathrm{i}>$ Escherichia coli $</ \mathrm{i}>$ by high-temperature cultivation. Appl Microbiol Biotechnol 2006, 73:172-180.

7. Mizobata T, Kagawa M, Murakoshi N, Kusaka E, Kameo K, Kawata Y, Nagai J: Overproduction of Thermus sp. YS 8-13 manganese catalase in Escherichia coli. European J Biochem 2000, 267:4264-4271.

8. Sizmann D, Keilmann C, Bock A: Primary structure requirements for the maturation in vivo of penicillin acylase from Escherichia coli ATCC 11105. Eur J Biochem 1990, 192:143-151.

9. Ignatova Z, Stoeva S, Galunsky B, Hörnle C, Nurk A, Piotraschke E, Voelter W, Kasche V: Proteolytic processing of penicillin amidase from Alcaligenes faecalis cloned in E.coli yields several active forms. Biotechnol Lett 1998, 20:977-982.

10. Arroyo M, de la Mata I, Acebal C, Castillon MP: Biotechnological applications of penicillin acylases: state-of-the-art. Appl Microbiol Biotechnol 2003, 60:507-514. 
11. Parmar A, Kumar H, Marwaha SS, Kennedy JF: Advances in enzymatic transformation of penicillins to 6-aminopenicillanic acid (6-APA). Biotechnol Adv 2000, 18:289-301.

12. Pedelacq JD, Cabantous S, Tran T, Terwilliger TC, Waldo GS: Engineering and characterization of a superfolder green fluorescent protein. Nat Biotechnol 2006, 24:79-88.

13. Castan P, Zafra O, Moreno R, de Pedro MA, Valles C, Cava F, Caro E, Schwarz $\mathrm{H}$, Berenguer J: The periplasmic space in Thermus thermophilus: evidence from a regulation-defective S-layer mutant overexpressing an alkaline phosphatase. Extremophiles 2002, 6:225-232.

14. Thein M, Sauer G, Paramasivam N, Grin I, Linke D: Efficient subfractionation of gram-negative bacteria for proteomics studies. J Proteome Res 2010 9:6135-6147.

15. Hobb Rl, Fields JA, Burns CM, Thompson SA: Evaluation of procedures for outer membrane isolation from Campylobacter jejuni. Microbiol 2009, 155:979-988.

16. Schnaitman CA: Effect of ethylenediaminetetraacetic acid, Triton X-100, and lysozyme on the morphology and chemical composition of isolate cell walls of Escherichia coli. J Bacteriol 1971, 108:553-563.

17. Schnaitman CA: Solubilization of the cytoplasmic membrane of Escherichia coli by Triton X-100. J Bacterio/ 1971, 108:545-552.

18. Buist G, Ridder AN, Kok J, Kuipers OP: Different subcellular locations of secretome components of Gram-positive bacteria. Microbiol 2006, 152:2867-2874.

19. Thomas JD, Daniel RA, Errington J, Robinson C: Export of active green fluorescent protein to the periplasm by the twin-arginine translocase (Tat) pathway in Escherichia coli. Mol Microbiol 2001, 39:47-53.

20. Molik S, Karnauchov I, Weidlich C, Herrmann RG, Klosgen RB: The Rieske $\mathrm{Fe} / \mathrm{S}$ protein of the cytochrome b6/f complex in chloroplasts: missing link in the evolution of protein transport pathways in chloroplasts? J Biol Chem 2001, 276:42761-42766.

21. Brouns SJ, Wu H, Akerboom J, Turnbull AP, de Vos WM, van der Oost J: Engineering a selectable marker for hyperthermophiles. J Biol Chem 2005, 280:11422-11431.

22. Xu Y, Weng CL, Narayanan N, Hsieh MY, Anderson WA, Scharer JM, Moo-Young M, Chou CP: Chaperone-mediated folding and maturation of the penicillin acylase precursor in the cytoplasm of Escherichia coli. Appl Environ Microbiol 2005, 71:6247-6253.

23. Wu MS, Pan KL, Chou CP: Effect of heat-shock proteins for relieving physiological stress and enhancing the production of penicillin acylase in Escherichia coli. Biotechnol Bioeng 2007, 96:956-966.

24. de Marco A, Deuerling E, Mogk A, Tomoyasu T, Bukau B: Chaperone-based procedure to increase yields of soluble recombinant proteins produced in E. coli. BMC Biotechnol 2007, 7:32

25. Bergeron LM, Lee C, Tokatlian T, HollrigI V, Clark DS: Chaperone function in organic co-solvents: experimental characterization and modeling of a hyperthermophilic chaperone subunit from Methanocaldococcus jannaschii. Biochim Biophys Acta 2008, 1784:368-378.

26. Bergeron LM, Tokatlian T, Gomez L, Clark DS: Redirecting the inactivation pathway of penicillin amidase and increasing amoxicillin production via a thermophilic molecular chaperone. Biotechnol Bioeng 2009, 102:417-424.

27. Duggleby HJ, Tolley SP, Hill CP, Dodson EJ, Dodson G, Moody PC: Penicillin acylase has a single-amino-acid catalytic centre. Nature 1995 373:264-268.

28. McDonough MA, Klei HE, Kelly JA: Crystal structure of penicillin G acylase from the Bro1 mutant strain of Providencia rettgeri. Protein Sci 1999, 8:1971-1981.

29. Kasche V, Galunsky B, Ignatova Z: Fragments of pro-peptide activate mature penicillin amidase of Alcaligenes faecalis. Eur J Biochem 2003, 270:4721-4728

30. Smith RJ: Calcium and bacteria. Adv Microb Physiol 1995, 37:83-133.

31. Hewitt L, Kasche V, Lummer K, Lewis RJ, Murshudov GN, Verma CS, Dodson GG, Wilson KS: Structure of a slow processing precursor penicillin acylase from Escherichia coli reveals the linker peptide blocking the active-site cleft. J Mol Biol 2000, 302:887-898.

32. Kasche V, Ignatova Z, Markl H, Plate W, Punckt N, Schmidt D, Wiegandt K, Ernst B: $\mathrm{Ca} 2+$ is a cofactor required for membrane transport and maturation and is a yield-determining factor in high cell density penicillin amidase production. Biotechnol Prog 2005, 21:432-438.
33. Jiang $Y M$, Tong WY, Wei DZ: Effects of induction starting time and Ca2+ on expression of active penicillin $\mathrm{G}$ acylase in Escherichia coli. Biotechnol Prog 2007, 23:1031-1037.

34. Vieille C, Burdette DS, Zeikus JG: Thermozymes. Biotechnol Annu Rev 1996, 2:1-83.

35. Antranikian $\mathrm{G}$, Vorgias $C E$, Bertoldo $C$ : Extreme environments as a resource for microorganisms and novel biocatalysts. Adv Biochem Eng Biotechnol 2005, 96:219-262.

36. Bertoldo C, Grote R, Antranikian G: Biocatalysis under extreme conditions. Biotechnology 2001, 10:61-103.

37. Torres-Guzmán R, de la Mata I, Torres-Bacete J, Arroyo M, Castillón MP, Acebal C: Substrate Specificity of Penicillin Acylase from Streptomyces lavendulae. Biochem Biophys Res Commun 2002, 291:593-597.

38. Torres-Bacete J, Hormigo D, Stuart M, Arroyo M, Torres P, Castillon MP Acebal C, Garcia JL, de la Mata I: Newly discovered penicillin acylase activity of aculeacin A acylase from Actinoplanes utahensis. Appl Environ Microbiol 2007, 73:5378-5381.

39. Arroyo MA, de la Mata IM, Acebal CA, Pilar Castillón MPC: Biotechnological applications of penicillin acylases: state-of-the-art. Appl Microbiol Biotechnol 2003, 60:507-514

40. Britton HTK, Robinson RA: J Chem Soc 1931, 1456-1462.

41. Joseph RE, Andreotti AH: Bacterial expression and purification of interleukin-2 tyrosine kinase: single step separation of the chaperonin impurity. Protein Expr Purif 2008, 60:194-197.

doi:10.1186/1475-2859-11-105

Cite this article as: Torres et al:: Functional expression of a penicillin acylase from the extreme thermophile Thermus thermophilus HB27 in Escherichia coli. Microbial Cell Factories 2012 11:105.

\section{Submit your next manuscript to BioMed Central and take full advantage of:}

- Convenient online submission

- Thorough peer review

- No space constraints or color figure charges

- Immediate publication on acceptance

- Inclusion in PubMed, CAS, Scopus and Google Scholar

- Research which is freely available for redistribution

Submit your manuscript at www.biomedcentral.com/submit
C BioMed Central 